\title{
Cytochemical Localization of Hydrogenase Activity in the Anaerobic Protozoa Trichomonas vaginalis, Plagiopyla nasuta and Trimyema compressum
}

\author{
By KOR B. ZWART, $†$ NICO K. GOOSEN, MARIAN W. VAN SCHIJNDEL, \\ CEES A. M. BROERS, CLAUDIUS K. STUMM AND \\ GODFRIED D. VOGELS* \\ Department of Microbiology, Faculty of Science, University of Nijmegen, Toernooiveld, \\ NL-6525 ED Nijmegen, The Netherlands
}

(Received 1 March 1988)

A cytochemical staining method was developed for the demonstration of hydrogenase activity in hydrogenosomes of Trichomonas vaginalis. After fixation in low concentrations of glutaraldehyde under strictly anaerobic conditions and incubation of these cells in the presence of $\mathrm{H}_{2}$ and the tetrazolium compound 2-(2'-benzothiazolyl)-5-styryl-3-(4'-phthalhydrazidyl)-tetrazolium chloride, an electron-dense deposit was produced in the hydrogenosomes. The method was used to demonstrate the hydrogenosomal nature of similar microbodies of the sapropelic ciliates Plagiopyla nasuta and Trimyema compressum.

\section{INTRODUCTION}

Many anaerobic sapropelic ciliates contain microbodies together with methanogenic endosymbionts (Van Bruggen et al., 1984, 1986; Stumm \& Zwart, 1986). Ultrastructurally the microbodies resemble the hydrogenosomes of trichomonads (Lindmark et al., 1975; Müller, 1980) and rumen ciliates (Yarlett et al., 1984). The microbodies are thought to be the source of $\mathrm{H}_{2}$ for the methanogenic bacteria. Cultivation of sapropelic ciliates in numbers high enough for the cell fractionation studies necessary to characterize these organelles biochemically is not yet possible. Furthermore, preliminary experiments aimed at the localization of hydrogenase activity in the ciliate Metopus striatus by cytochemical staining were unsuccessful (K. B. Zwart $\&$ C. A. M. Broers, unpublished results). Thus there is a need for a specific staining procedure to demonstrate hydrogenase activity in anaerobic protozoa. In this paper we describe a method which was developed for the cytochemical staining of hydrogenase in the hydrogenosomes of Trichomonas vaginalis, an organism in which hydrogenosomes have been characterized thoroughly (Lindmark et al., 1975; Müller, 1980). Furthermore we report the application of this method in two sapropelic ciliates, Plagiopyla nasuta and Trimyema compressum. (Preliminary results of this study were presented at the Fourth International Symposium on Microbial Ecology, August 24-29, 1986, Ljubljana, Yugoslavia.)

\section{METHODS}

Organisms and cultivation. Trichomonas vaginalis, isolated from a patient at the local Canisius-Wilhelmina Hospital, was grown anaerobically in serum flasks at $37^{\circ} \mathrm{C}$ under a $\mathrm{N}_{2}$ atmosphere $(30 \mathrm{kPa})$ in the medium of Feinberg \& Whittington (1957). Stock cultures were stored at $-70^{\circ} \mathrm{C}$ in $20 \%(\mathrm{v} / \mathrm{v})$ glycerol.

† Present address: Institute for Soil Fertility, Oosterweg 92, PO Box 30003, NL-9750 RA Haren, The Netherlands.

Abbreviations: BSPT, 2-(2'-benzothiazolyl)-5-styryl-3-(4'-phthalhydrazidyl)-tetrazolium chloride; MNA, methylnadic anhydride. 
Plagiopyla nasuta, isolated from the sapropel of a 2001 aquarium, was grown anaerobically in serum flasks at $20{ }^{\circ} \mathrm{C}$ under $\mathrm{N}_{2} / \mathrm{CO}_{2}(19: 1, \mathrm{v} / \mathrm{v})$ at atmospheric pressure in a dilute salt medium supplemented with $0.02 \%(\mathrm{w} / \mathrm{v})$ dried grass (Goosen $e$ t al., 1988), and a mixture of bacteria enriched anaerobically from the sapropel on nutrient broth (Oxoid). Growing protozoal cells were harvested under anaerobic conditions from culture samples $(3 \mathrm{ml})$ with a cell density of approximately 200 cells $\mathrm{ml}^{-1}$.

Trimyema compressum, isolated from a sludge backing pond of a wastewater treatment plant near Nijmegen, was grown anaerobically in serum flasks at $20^{\circ} \mathrm{C}$ under a $\mathrm{N}_{2}$ atmosphere $(30 \mathrm{kPa})$ in a medium which contained $\mathrm{KH}_{2} \mathrm{PO}_{4} / \mathrm{Na}_{2} \mathrm{HPO}_{4}(4 \mathrm{mM}), \mathrm{CaCl}_{2}(0.1 \mathrm{mM}), \mathrm{MgSO}_{4}(1 \mathrm{~mm})$ and $\mathrm{Na}_{2} \mathrm{~S}(0.4 \mathrm{~mm})$ adjusted to $\mathrm{pH} 7 \cdot 3$, and supplemented with Pseudomonas fluorescens $\left(10^{5}-10^{6}\right.$ cells $\left.\mathrm{ml}^{-1}\right)$. Growing protozoal cells were harvested under anaerobic conditions from culture samples $(3 \mathrm{ml})$ with a cell density of approximately $2000 \mathrm{cells}^{-1}$.

Hydrogenase activity of Trich. vaginalis. Exponentially growing cells were harvested under anaerobic conditions by centrifugation at $1000 \mathrm{~g}$ for $10 \mathrm{~min}$, when cultures had reached a cell density of approximately $10^{6} \mathrm{cells}^{-1}$ (24-28 $\mathrm{h}$ after inoculation). Subsequently, the cells were washed twice in solution $\mathrm{A}$, which contained sucrose (225 mM), $\mathrm{KCl}(20 \mathrm{mM}), \mathrm{KH}_{2} \mathrm{PO}_{4}(10 \mathrm{mM}), \mathrm{MgCl}_{2}(5 \mathrm{mM})$, EDTA $(1 \mathrm{mM})$ and Tris $(20 \mathrm{mM})$ adjusted to $\mathrm{pH} 7 \cdot 2$ with $\mathrm{HCl}$.

Hydrogenase activity of intact cells or of cells disrupted by sonication was measured at $22{ }^{\circ} \mathrm{C}$ according to the method of Lindmark \& Müller (1973), which was modified as follows. $\beta$-Mercaptoethanol was omitted since either the reaction was measured under strictly anaerobic conditions, or the effect of oxygen on enzyme activity was studied. In addition, benzyl viologen instead of methyl viologen was used as an electron acceptor. The effect of fixation on hydrogenase activity was studied by treating cells with formaldehyde or glutaraldehyde (both 0.5 or $1.0 \%, \mathrm{v} / \mathrm{v}$ ) for $10 \mathrm{~min}$ at $0{ }^{\circ} \mathrm{C}$ under aerobic or anaerobic conditions. Protein was measured according to Bradford (1976).

Cytochemistry of Trich vaginalis. Cells were harvested, rinsed twice in solution $\mathrm{A}$, prefixed for 10 minutes at $0{ }^{\circ} \mathrm{C}$ in $0.5 \%(\mathrm{v} / \mathrm{v})$ glutaraldehyde in $0.1 \mathrm{M}-\mathrm{KH}_{2} \mathrm{PO}_{4} / \mathrm{K}_{2} \mathrm{HPO}_{4}$ buffer (PPB), pH 7.2, containing $0.25 \mathrm{M}$-sucrose and subsequently rinsed again twice in PPB plus sucrose to remove glutaraldehyde. Prefixed cells were incubated in serum flasks $(10 \mathrm{ml})$ for $30-90 \mathrm{~min}$ at $22^{\circ} \mathrm{C}$ in PPB containing sucrose and 2-(2'-benzothiazolyl)-5-styryl-3-(4'phthalhydrazidyl)-tetrazolium chloride (BSPT, $0.25 \mathrm{mg} \mathrm{ml}^{-1}$ ) as electron acceptor (Doddema et al., 1979;
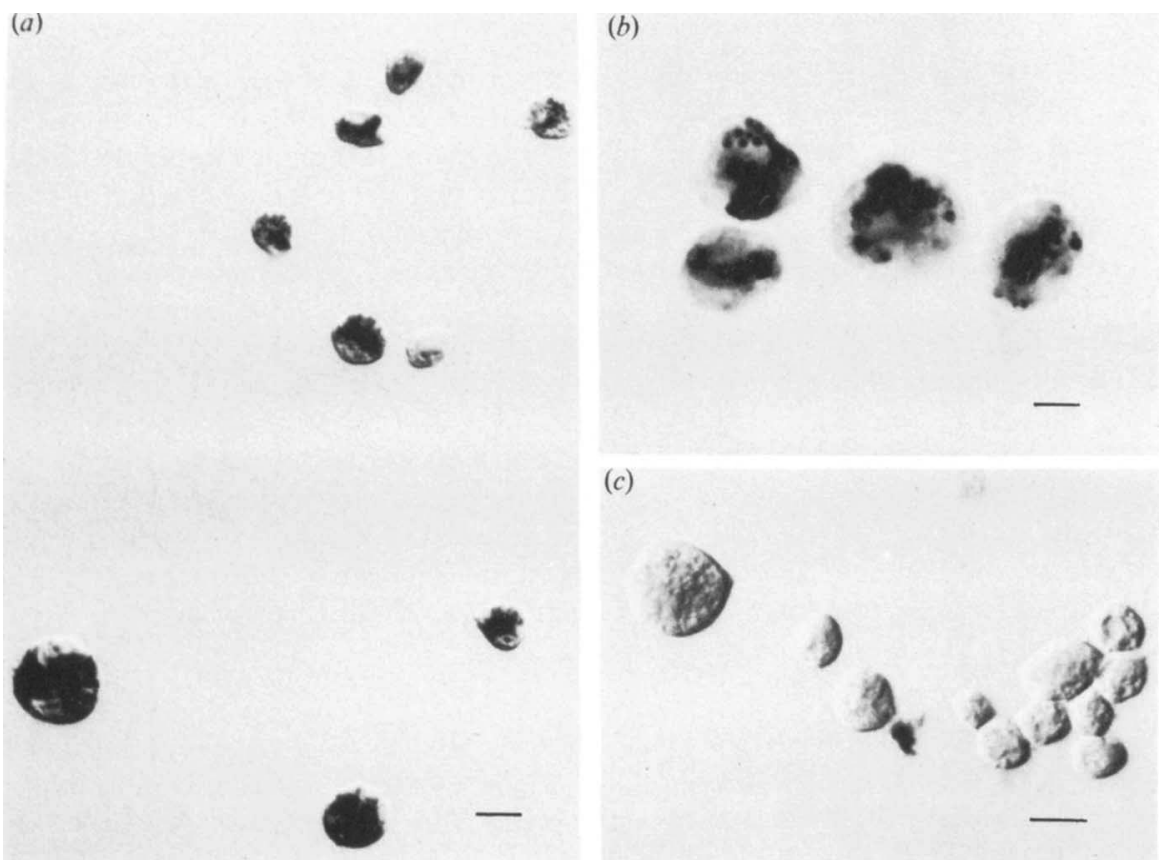

(c)

Fig. 1. Light micrographs of Trich. vaginalis fixed anaerobically in $0.5 \%$ glutaraldehyde and stained for hydrogenase activity with BSPT as electron acceptor. (a) Cells incubated in the presence of $\mathrm{H}_{2}$ showing a positive reaction in the majority of cells (differential interference contrast, DIC). (b) Detail of cells incubated in the presence of $\mathrm{H}_{2}$ showing positively stained granules (bright field). (c) Control cells incubated in the presence of $\mathrm{N}_{2}$ showing no staining (DIC). Bars, $10 \mu \mathrm{m}$. 
Shannon, 1982) with $\mathrm{H}_{2}(30 \mathrm{kPa})$ in the headspace. In control experiments $\mathbf{N}_{2}(30 \mathrm{kPa})$ was used instead of $\mathbf{H}_{2}$. The reaction was followed by light microscopy and stopped by rinsing the cells in PPB plus sucrose. Up to this point strictly anaerobic conditions were maintained. Reduced BSPT formed during the incubation was modified into an electron-dense product in a reaction with $2 \%(\mathrm{w} / \mathrm{v}) \mathrm{OsO}_{4}$ in distilled water (Shannon, 1982). After rinsing in PPB containing sucrose, the cells were postfixed in $3 \%(\mathrm{v} / \mathrm{v})$ glutaraldehyde. Specimens were dehydrated in an alcohol series and embedded in Araldite or Epon 812 resin with or without methylnadic anhydride (MNA). Ultrathin sections were cut with a diamond knife and examined in a Philips EM 201 or EM 300.

Cytochemistry of sapropelic ciliates. Cytochemical procedures for sapropelic ciliates were applied as described for Trich. vaginalis with the following modifications. Cells were harvested, immediately prefixed in $0 \cdot 35 \%(\mathrm{v} / \mathrm{v}$, final concentration) glutaraldehyde in culture medium for 10 minutes at $0{ }^{\circ} \mathrm{C}$ and rinsed three times in culture medium without sulphide. The conditions for incubation with BSPT were as described for Trich. vaginalis, except that the incubation time was $3 \mathrm{~h}$ instead of $30-90 \mathrm{~min}$. The reaction was stopped by rinsing the cells twice in PPB plus sucrose and subsequently in $0.1 \mathrm{M}$-cacodylate buffer, $\mathrm{pH} \mathrm{7.2.} \mathrm{After} \mathrm{formation} \mathrm{of} \mathrm{an} \mathrm{electron-dense} \mathrm{product} \mathrm{with}$ $2 \% \mathrm{OsO}_{4}$ in cacodylate buffer, cells of Trim. compressum were rinsed and postfixed in $6 \%(\mathrm{v} / \mathrm{v})$ glutaraldehyde in cacodylate buffer. Cells of $P$. nasuta were postfixed in $3 \%(v / v)$ glutaraldehyde in cacodylate buffer prior to the reaction with $1 \% \mathrm{OsO}_{4}$. This method resulted in a better preservation of the ultrastructure of ciliates than the method used for Trich. vaginalis. After embedding in Araldite, ultrathin sections were cut with glass knives.

\section{RESULTS AND DISCUSSION}

Preliminary experiments with Metopus striatus cells had indicated that fixation in $2.5 \%$ glutaraldehyde severely inhibited hydrogenase activity (unpublished results). Therefore the

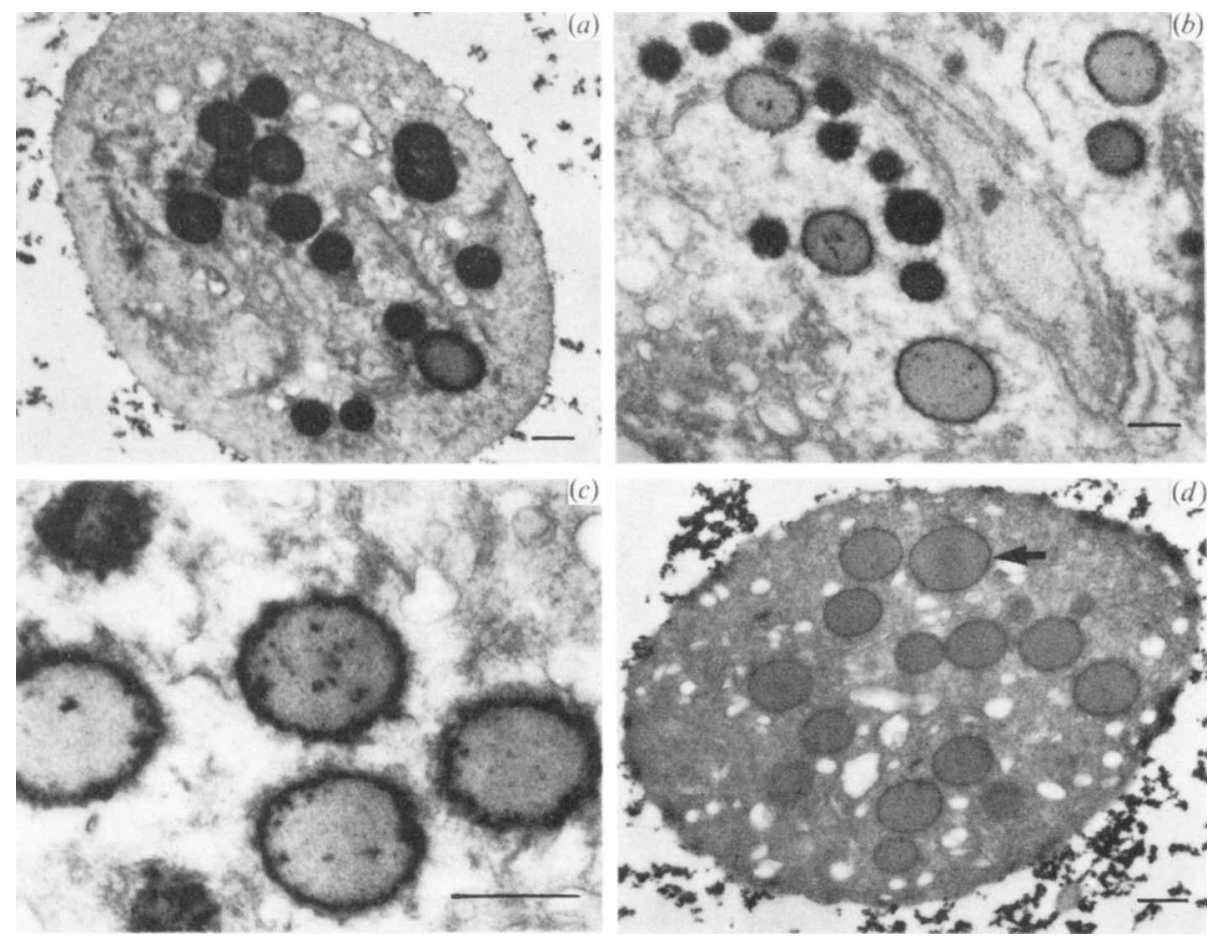

Fig. 2. Electron micrographs of Trich. vaginalis fixed and stained as described for Fig. 1. (a) Cell incubated in the presence of $\mathrm{H}_{2}$. A positive reaction is shown in the hydrogenosomes. The deposit outside the cells is a result of a non-specific reaction also occurring in control cells (see $d$ ). (b) Detail of a cell incubated in the presence of $\mathrm{H}_{2}$. In some of the hydrogenosomes the centre of the matrix remained unstained. (c) Detail of a cell incubated in the presence of $\mathrm{H}_{2}$ showing partly stained hydrogenosomes. (d) Control cell incubated in the presence of $\mathrm{N}_{2}$. Note the absence of staining products in the hydrogenosomal matrix, the light deposit on the hydrogenosomal membrane (arrow) and the deposit outside the cell. Bars, $0.5 \mu \mathrm{m}$. 


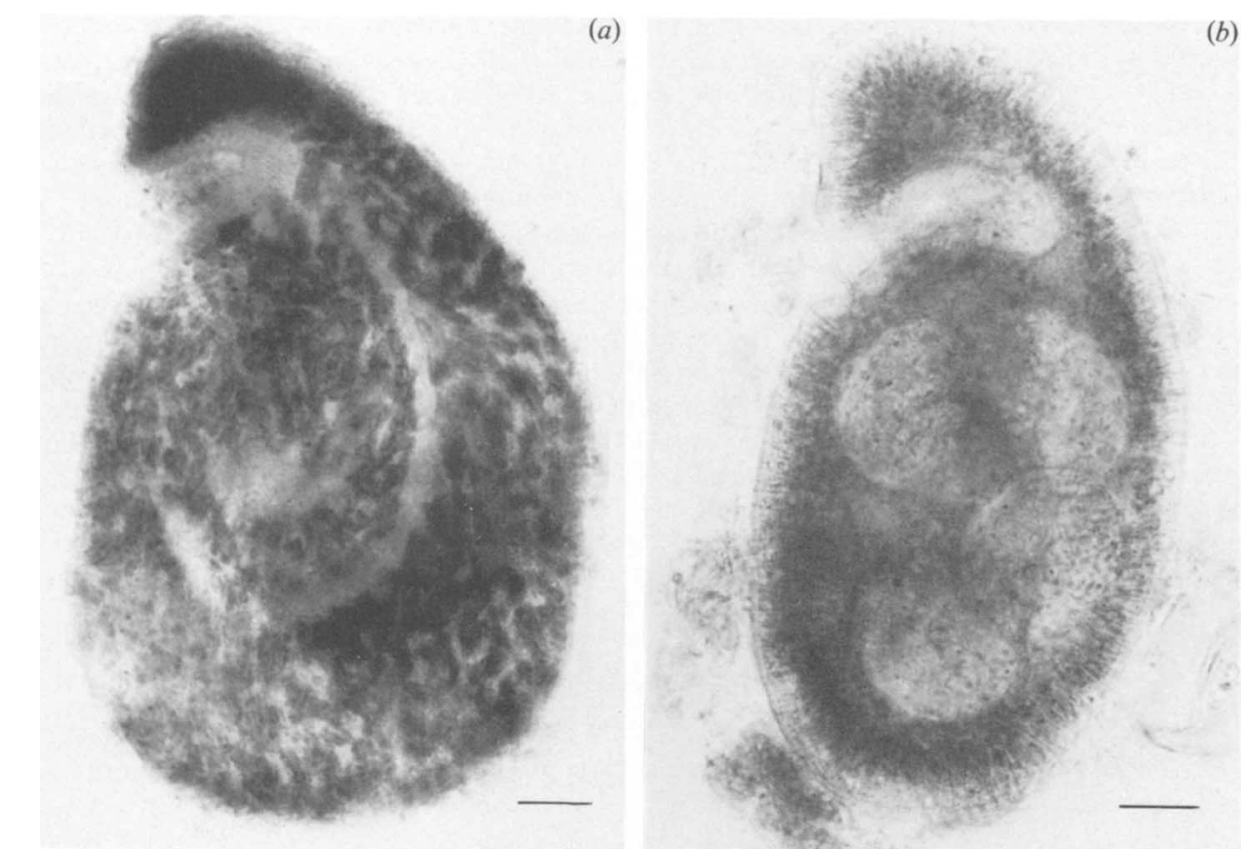

Fig. 3. Light micrographs (bright field) of $P$. nasuta fixed anaerobically in $0.35 \%$ glutaraldehyde and stained for hydrogenase activity with BSPT as electron acceptor. (a) Cell incubated in the presence of $\mathrm{H}_{2}$ showing positive staining located in clusters. (b) Control cell incubated in the presence of $\mathrm{N}_{2}$ showing no staining. Bars, $10 \mu \mathrm{m}$.

effect of fixation on hydrogenase activity was studied in more detail in Trich. vaginalis. Unfixed

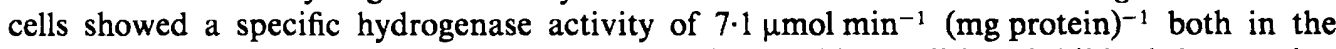
absence and the presence of oxygen. Fixation under aerobic conditions inhibited the reaction completely. Trich vaginalis hydrogenase is oxygen labile (Lindmark \& Müller, 1973; Lindmark et al., 1975), and possibly fixation facilitated passage of oxygen across the cell membrane, which resulted in enzyme inactivation. Anaerobic fixation in $1 \%$ glutaraldehyde or $1 \%$ formaldehyde strongly inhibited enzyme activity to $15 \%$ of the original value, but after anaerobic fixation in $0.5 \%$ glutaraldehyde $66 \%$ of the original activity was retained.

When cells were fixed anaerobically in $0.5 \%$ glutaraldehyde and subsequently incubated in the reaction mixture for hydrogenase staining in the presence of $\mathrm{H}_{2}$, they showed blue/violetstained granules inside $40-90 \%$ of the cells (Fig. $1 a, b$ ), whereas in control incubations staining was absent (Fig. 1c). In ultrathin sections of these cells embedded in Araldite, an electron-dense deposit was observed exclusively in the hydrogenosomes (Fig. $2 a, b$ ). Similar results were found in cells embedded in Epon 812 with or without MNA (not shown). In some of the organelles the centre of the matrix remained unstained (Fig. $2 b, c$ ). Whether this was due to a peripheral localization of the enzyme or to poor penetration of staining chemicals is not known. Obviously, in Trich. vaginalis strictly anaerobic conditions during the entire staining procedure, i.e. until the reduction of BSPT was completed, were required for a successful result. In control cells no deposit was observed within the matrix (Fig. 2d) but in some of the cells the membrane of the microbodies stained slightly (Fig. $2 d$ ). At present no conclusive explanation of this phenomenon can be given. Possibly it is due to endogenous activity of malate dehydrogenase, but no experiments were done to confirm this hypothesis. To our knowledge, the described result is the first cytochemical demonstration of hydrogenase activity in a eukaryotic organism. The technique was used earlier in bacteria by Doddema et al. (1979).

After having established the proper reaction conditions for Trich. vaginalis, the technique was applied for the localization of hydrogenase activity in two anaerobic sapropelic ciliates, 

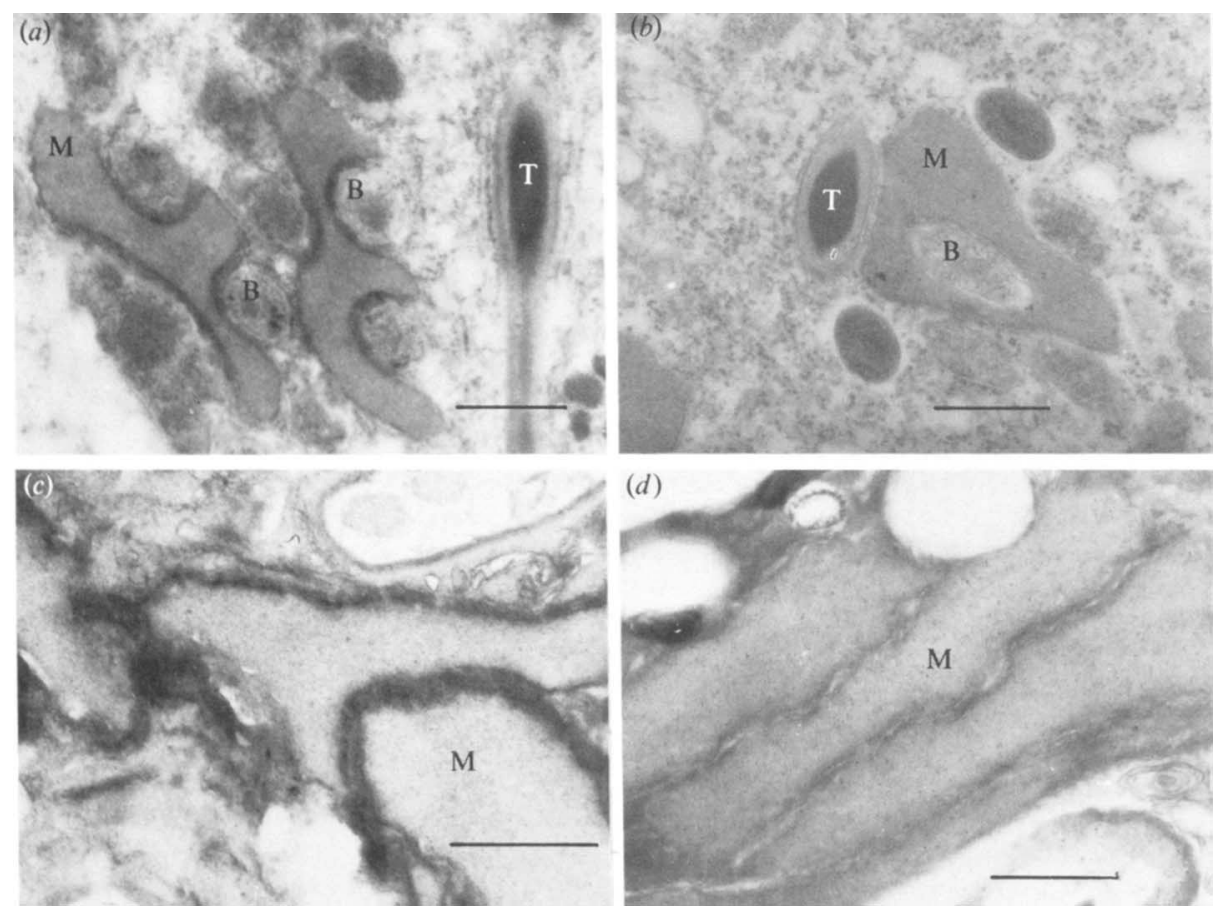

Fig. 4. Electron micrographs of $P$. nasura $(a, b)$ and Trim. compressum $(c, d)$ fixed and stained as described for Fig. 3. (a) Detail of a cell incubated in the presence of $\mathrm{H}_{2}$. A positive reaction is shown with the staining product located on the membranes of the microbodies, especially at the sides associated with the methanogens. The electron density of trichocysts is a normal phenomenon and not due to the presence of BSPT. (b) Detail of a control cell incubated in the presence of $\mathrm{N}_{2}$. No staining product is visible. (c) Detail of a cell incubated in the presence of $\mathrm{H}_{2}$ showing a staining product located on the membranes of the microbodies. Note the absence of endosymbionts. (d) Detail of a control cell incubated in the presence of $\mathbf{N}_{2}$. No staining product is formed. $\mathbf{M}$, microbodies; $B$, methanogenic endosymbionts; $T$, trichocysts. Bars, $0.5 \mu \mathrm{m}$.

Plagiopyla nasuta and Trim. compressum. In $P$. nasuta clusters of microbodies in a very close association with methanogenic bacteria are scattered throughout the cytoplasm (Stumm \& Zwart, 1986; Goosen et al., 1988). The results are shown in Figs 3 and 4. After incubation for $3 \mathrm{~h}$ in the reaction mixture for staining hydrogenase activity in the presence of $\mathrm{H}_{2}$, preparations examined by light microscopy showed a blue/violet deposit arranged cluster-wise in each cell of $P$. nasuta (Fig. $3 a$ ). In control cells, no reaction occurred (Fig. $3 b$ ). In ultrathin sections of cells embedded in Araldite, an electron-dense deposit was formed close to the membrane of the microbodies, especially at the immediate vicinity of the methanogens (Fig. $4 a$ ). In control cells no reaction product was formed (Fig. $4 b$ ).

Cells of Trim. compressum were harvested that had lost their endosymbiotic methanogens, as confirmed by epifluorescence microscopy (Doddema \& Vogels, 1978) and by electron microscopy. The phenomenon of loss of endosymbionts was also reported by Wagener \& Pfennig (1987). Microbodies, however, were still present and these organelles showed a positive reaction after staining for hydrogenase activity (Fig. $4 c$ ). The reaction product was not uniformly distributed over the organelles but was deposited at the periphery. Again in control cells no deposit was found (Fig. $4 d$ ).

The incubation time used for ciliates was two to three times longer than that for Trich. vaginalis, probably indicating a much lower enzymic activity. This may also explain why in ciliates no reaction product was formed throughout the microbodies and why in control cells no staining of the membrane occurred. On the other hand, hydrogenase may indeed be located on 
the microbody membrane, and malate dehydrogenase may be absent in these cells since it could not be demonstrated in hydrogenosomes of some rumen ciliates (Yarlett et al., 1981, 1983, 1984). The results strongly indicate the presence of hydrogenase activity in the microbodies of sapropelic ciliates. This study validates the hypothesis mentioned by Van Bruggen et al. (1984) that these organelles might produce $\mathrm{H}_{2}$, which is utilized subsequently by the methanogenic endosymbionts, and consequently the methanogen-associated organelles may be referred to as hydrogeriosomes. Further characterization of these organelles by cytochemical techniques is being undertaken at present in order to elucidate their metabolic activities. The technique for staining hydrogenase activity as described in the present paper may be helpful in characterizing organelles of cells which cannot yet be cultured in numbers high enough for the study of isolated organelles.

We ackhowledge Dr M. Müller (Rockefeller University, New York, USA) for giving valuable suggestions and R. Sinke for preparing the electron micrographs'of Trim. compressum. Part of this study was financed by The Foundation for Fundamental Biological Research (BION) which is subsidized by the Netherlands Organization for Scientific Research (NWO).

\section{REFERENCES}

BradFoRd, M. M. (1976). A rapid and sensitive method for the quantitation of microgram quantities of protein utilizing the principle of protein-dye binding. Analytical Biochemistry 72, 248-254.

DODDEMA, H. J. \& VoGELS, G. D. (1978). Improved identification of methanogenic bacteria by fluorescence microscopy. Applied and Environmental Microbiology 36, 752-754.

Doddema, H. J., VAN der DRift, C., Vogels, G. D. \& VeenhuIs, M. (1979). Chemiosmotic coupling in Methanobacterium thermoautotrophicum: hydrogendependent adenosine 5'-triphosphate synthesis by subcellular particles. Journal of Bacteriology 140, 1081-1089.

FeinberG, J. G. \& Whittington, J. M. (1957). A culture medium for Trichomonas vaginalis Donné and species of Candida. Journal of Clinical Pathology 10 , 327-329.

Goosen, N. K., Horemans, A. M. C., Hillebrand, S. J. W., Stumi, C. K. \& Vogels, G. D. (1988). Cultivation of the sapropelic eiliate Plagiopyla nasuta Stein and isolation of the endosymbiont Methanobacterium formicicum. Archives of Microbiology (in the Press).

LINDMARK, D. G. \& MÜlleR, M. (1973). Hydrogenosome, a cytoplasmic organelle of the anaerobic flagellate Tritrichomonas foetus, and its role in pyruvate metabolism. Journal of Biological Chemistry 248, 7724-7728.

Lindmark, D. G., Müller, M. \& Shio, H. (1975). Hydrogenosomes in Trichomonas vaginalis. Journal of Parasitology 63, 552-554.

MÚlLER, M. (1980). The hydrogenosome. Symposia of the Society for General Microbiology 30, 127-142.

ShanNon, W. A. (1982). Use of BSPT in dehydrogenase histochemistry. Histochemical Journal 14, 166167.

StumM, C. K. \& ZWART, K. B. (1986). Symbiosis of protozoa with hydrogen-utilizing methanogens. Microbiological Sciences 3, 100-105.

Van Bruggen, J. J. A., Zwart, K. B., van AsSema, R. M., Stumm, C. K. \& Vogels, G. D. (1984). Methanobacterium formicicum, an endosymbiont of the anaerobic ciliate Metopus striatus McMurrich. Archives of Microbiology 139, 1-7.

Van Bruggen, J. J. A., Zwart, K. B., Hermans, J. G. F., van Hove, E. M., Stumm, C. K. \& Vogels, G. D. (1986). Isolation and characterization of Methanoplanus endosymbiosus sp. nov., an endosymbiont of the marine sapropelic ciliate Metopus contortus Quennerstedt. Archives of Microbiology 144, 367-374.

Wagener, S. \& Pfennig, N. (1987). Monoxenic culture of the anaerobic ciliate Trimyema compressum Lackey. Archives of Microbiology 149, 4-11.

Yarlett, N., HaNN, A. C., Lloyd, D. \& Williams, A. G. (1981). Hydrogenosomes in the rumen protozoan Dasytricha ruminantium Schuberg. Biochemical Journal 200, 365-372.

Yarlett, N., HanN, A. C., Lloyd, D. \& Wilitams, A. G. (1983). Hydrogenosomes in a mixed isolate of Isotricha prostoma and Isotricha intestinalis from ovine rumen contents. Comparative Biochemistry and Physiology 74B, 357-364.

Yarlett, N., Coleman, G. S., Williams, A. G. \& LLOYD, D. (1984). Hydrogenosomes in known species of rumen entodiniomorphid protozoa. FEMS Microbiology Letters 21, 15-19. 